\title{
G-BASE: Baseline geochemical mapping of Great Britain and Northern Ireland
}

\author{
C.C. Johnson, N. Breward, E.L. Ander \& L. Ault
}

British Geological Survey, Keyworth, Nottingham NG12 5GG, United Kingdom

(e-mail:ccj@bgs.ac.uk)

\section{ABSTRACT:}

The Geochemical Baseline Survey of the Environment is a long established highresolution regional geochemical mapping project run by the British Geological Survey. A project initially stimulated for mineral exploration and to assist geological mapping has successfully evolved into a survey that has many environmental applications. Much of the current demand for surface geochemical data is driven by legislation. The geochemical mapping, originally based on the collection of drainage samples, has expanded to include soils and a further suite of determinands in stream waters. The methodology of the project and application of the baseline data are described and issues common to worldwide geochemical mapping programmes are discussed.

KEYWORDS: geochemical mapping; soil; stream sediment; stream water 


\section{INTRODUCTION}

G-BASE (Geochemical Baseline Survey of the Environment) is a long established systematic geochemical mapping project that is indirectly funded by government through the UK Natural Environment Research Council (NERC) and is one of the British Geological Survey's (BGS) core science activities. When sampling commenced in the late 1960s the work was stimulated by mineral exploration and to assist geological mapping but now this high-resolution survey has many environmental applications. Much of the renewed demand for baseline geochemical information of the surface environment is legislatively driven.

The geochemical mapping methods and techniques established by Professor Jane Plant in BGS have now been used by several generations of geochemists both in the UK and in many parts of the world. Through the experiences of the G-BASE project, BGS continues to make significant contributions to international initiatives on geochemical mapping such as the recommendations for international geochemical mapping (Darnley et al 1995) and the FOREGS (Forum of European Geological Surveys) European geochemical baseline project (Plant et al 1997 and Salminen et al 1998).

The use of stream sediments in geochemical mapping derives from the fact that the active sediment in a stream bed can be used to give an approximation of the chemical composition of materials derived from the catchment area upstream of the sampling site. Regional geochemical mapping using stream sediments grew out of developments in the use of stream sediment sampling for mineral prospecting (Hawkes and Bloom 1955). The first comprehensive geochemical mapping in the UK was carried out by the Applied Geochemistry Research Group at Imperial College London. The Wolfson Geochemical Atlas of England and Wales (Webb et al 1978) 
remains the only completed regional geochemical stream sediment survey of England. A rapid field sampling programme carried out in the space of just one year (1969) collected stream sediments from 49464 sites in England and Wales giving an approximate sampling density of one sample every 3 square kilometres. However, this density does not account for the unsampled urban areas and regions of no surface drainage (e.g. over chalk).

McGrath \& Loveland (1992) produced a soil geochemical atlas of England and Wales. Surface soils were collected at a density of 1 sample per $25 \mathrm{~km}^{2}$ from nonurban areas and determined for "total" (acid extractable) and extractable concentrations of major elements, nutrients and some trace elements. A soil geochemical atlas of Northern Ireland has also been completed by Jordan et al 2000 targeted at lowland agricultural soils. In this over 6000 soil samples were collected from almost every kilometre square in the lowland area of Northern Ireland.

In 1968 the Institute of Geological Sciences (IGS) (now BGS) began regional geochemical sampling in the northern Highlands of Scotland aimed at producing maps to show the distribution of trace elements in stream sediments. Prior to this, BGS geochemical investigations were mainly involved with uranium reconnaissance work, a programme supported by the UK Atomic Energy Authority. Systematic sampling for the regional geochemistry started in Caithness and Sutherland in 1968 then Orkney and Shetland and the work has progressed southwards from northern Scotland ever since. There was a close synergy between the regional geochemical mapping project and BGS's Mineral Reconnaissance Programme (MRP) (1972 - 1997). The MRP was a multidisciplinary programme, using geochemistry to do targeted mineral exploration. Initially the MRP was concerned with base metals but later effort focused 
on strategic metals such as manganese and tungsten and on other commodities such as barite, gold and the platinum-group metals.

Figure 1 shows the current extent of the geochemical baseline mapping with approximately eighty percent of the British land area sampled. Whilst the south of England represents one fifth of the area to be sampled this region contains one third of the country's population and has the greatest legislatively driven demand for baseline geochemical data. Sampling is carried out during the summer months (JuneSeptember) by earth and environmental sciences students during their vacation. Continuous progress has been made, sampling between 2000 - 5000 sites each summer - resources for the project have varied according the BGS's commitments to other projects. At the current rate of progress the projected completion of the sampling would be between 2015-2020. To-date, over 105,000 stream sediments, 25,000 soils and 65,000 stream waters have been collected (see Table 1). The urban part of the G-BASE work is described elsewhere in this volume (Fordyce et al This Volume). Typical uses for the baseline geochemical methods and data during the course of a year are summarised in Table 2.

\section{METHODS}

\section{Sampling}

All G-BASE field procedures are documented in a field procedures manual (Johnson et al 2003) that is updated annually to ensure minor procedural variations between sampling campaigns are recorded. Stream sediment sampling methods have changed little since the 1970s following the comprehensive orientation studies of Plant (1971). The most significant change is the increase in different sample types collected. What initially started as a regional geochemical mapping survey based on drainage sediments has expanded to include soil sampling and a more extensive suite of water 
sample analyses (Simpson et al 1993). A multi-media survey is more efficient in terms of sampling costs and extends the uses to which the geochemical mapping can be applied. The sampling methods used by G-BASE are summarised Table 3.

Two types of site are sampled, namely a drainage site and a soil site. A sample of stream sediment, stream water and a panned heavy mineral concentrate is collected from each drainage site located on small streams $\left(1^{\text {st }}\right.$ or $2^{\text {nd }}$ order) to give a sampling density of one sample per 1.5 to $2 \mathrm{~km}^{2}$. A diagrammatic representation of a sampling site plan is given in Figure 2. Sediments and waters are analysed for a large range of determinands (see Table 3), the panned concentrates are only studied in detail or submitted for analysis if follow-up work is required. A suite of water samples is collected in a manner appropriate to the method by which they are to be analysed.

Two soil samples are collected from each soil site representing surface soil (approx 5 to $20 \mathrm{~cm}$ ) and deeper soil (approx 35 to $50 \mathrm{~cm}$ ) though in areas of shallow soil development the "deeper" soil can often be of equivalent depth to the surface soil. Initially the deeper soils were collected only in areas where there was no surface drainage, for example, in areas of chalk bedrock, to give baseline information where none was available from stream sediments (e.g. BGS 1996). However, as G-BASE has moved southwards into lowland areas where agriculture is more intensive and population density is greater, the demand for soil geochemical data has increased. G-BASE now routinely collects soils from every second kilometre square of the British National Grid by random selection within each square, avoiding transport routes, domestic and public gardens, and other seriously disturbed ground. In urban areas soils are sampled at a greater density with four sample sites located within each National Grid kilometre square. Sample sites are located at the centre of 500 x $500 \mathrm{~m}$ sub-cells within each square but the nature of the urban environment generally does 
not allow a completely regular sampling grid (see Fig. 2). Urban areas are defined from 1:50 000 scale topographic maps (Ordnance Survey ${ }^{\circledR}$ Landranger maps) on which urban and industrial areas are characterised by a high density of buildings.

\section{Chemical Analyses}

Analytical methods have changed considerably in the thirty-five years since the project began. More elements can now be measured at ever-greater accuracy and precision and down to lower concentration levels. Initially, direct current arc optical emission spectroscopy (OES) was the method employed. It is a multi-element technique that can be used directly on solids. In the early days, before the advances in electronics and computing, photographic OES was used. The intensities of the spectral lines from samples, captured on photographic plates, were compared with spectra from standards of known concentration. This technique was only practical for a small range of elements and, as at that time atomic absorption spectrometry (AAS) following an acid extraction was a more reliable method for $\mathrm{Cu}, \mathrm{Pb}$ and $\mathrm{Zn}$, these elements were determined by AAS. In this period mineral reconnaissance was an important part of the work and an acid extraction gave a good indication of base metal mineralisation.

In later years a direct reading spectrometer (DR), utilising photomultipliers for detection and a computer for calibration and concentration calculation, was used. This more automated method allowed for more efficient determination of a greater number of elements. The determination of $\mathrm{Cu}, \mathrm{Pb}$ and $\mathrm{Zn}$ by this technique, when compared to AAS data on the same samples, was appropriate for geochemical mapping at that time.

Early in the G-BASE project, $U$ was determined in stream sediments by the delayed neutron method of analysis (DNM) and in the second half of the 1970s, As 
and $\mathrm{Sb}$ were added to the programme as pathfinders for hydrothermal gold mineralisation. The latter elements were determined by AAS following an acid attack and solvent extraction.

Improvements in X-ray fluorescence spectrometry (XRFS) systems coupled with the advances in computing have made XRFS analysis a viable option for geochemical mapping, and since 1990, it has been used to determine the main multi-element suite together with U, As and Sb. Wavelength-dispersive (WD) XRFS (Ingham and Vrebos 1994) using a Philips PW1480 sequential spectrometer and two Philips PW2400 sequential spectrometers is used for the determination of major and trace elements. The spectrometers are controlled using Philips X40 application software package. Calibrations are performed using the manufacturer's calibration algorithms, making corrections for matrix effects and spectral line overlap. Up to two line-overlap interferences can be corrected for, using the X40 software. In conjunction with the WD-XRFS an energy-dispersive (ED) XRFS (PANalytical Epsilon 5) is now also used to determine the heavier elements Ag to Ce.

In the early days of the project stream water samples were analysed for a restricted number of determinands. Conductivity and $\mathrm{pH}$ were measured using portable field equipment and U was determined by DNM. Bicarbonate (by titration) and fluoride (by selective-ion electrode) were determined from the early 1980s, chloride and nitrate (by ion chromatography) being added to the programme from the late 1980s. Multielement analysis by inductively coupled plasma atomic emission spectrometry (ICPAES) of a larger number of water samples also began in the 1980s. A Fisons/ARL 3580 ICP-AES was used to determine 27 elements in stream waters. This was complemented by a quadrupole inductively coupled plasma mass spectrometer (ICP- 
MS), a VG Plasmaquad PQ 2+ in the 1990s; the ICP-MS being able to determine several trace elements in natural waters that are below detection limit for ICP-AES.

\section{Data Management}

Whilst sampling methods and equipment have changed little since the mapping programme began, data management, like the chemical analysis, has changed significantly with developments in hardware. Early field data and analytical results were hand written and manually typed into reports and tables. The systematic and standardised method of reporting field data has been achieved from the commencement of the work using field cards (Fig. 3) that have changed little since the 1970s. These were based on 80 column computer punch cards which ensured all important data were recorded within fields (site geology and land use for example) that were compulsory to fill, usually with coded information. These codes are standardised throughout BGS and are used by other geological disciplines during fieldwork. The codes also tend to be hierarchical which helps with selective retrieval of samples during interpretation. For example, the four-letter land use code for woodland is AE00, whereas for deciduous, coniferous and mixed woodland the codes are AEA0, AEB0 and AEC0 respectively. All types of woodland can be selected simply by using the first two letters of the code.

As the volume of geochemical data grew the storage demands continually pushed computer hardware to its limits. The project has always been at the forefront of computer-aided map plotting and interpretation, though computer generated maps of the 1970s (e.g. Plant \& Rhind 1974), considered spectacular at the time because of the "cutting-edge" computer automation, can now be routinely created on a desk-top 
computer. The basis for all data interpretation and map production is a sound quality controlled (Plant et al 1975) and assured database. On receipt from the laboratories the G-BASE analytical results go through a series of data conditioning procedures. Here data conditioning is used in the sense of "rendering fit for purpose" and for some data applications not all the conditioning procedures are required. For example, levelling the data to a national standard is only required to plot seamless national geochemical maps (Fig. 4) and not required if studying a small region such as a local administrative area. However, standard error checking and use of control samples to monitor precision and accuracy is required to be done on all data before it is loaded to the BGS Geochemistry Database. Duplicate, replicate, blank, primary and secondary reference materials are all included in every batch of samples submitted for analysis. The chemical laboratories monitor accuracy and precision by the inclusion of international (primary) reference materials before and after every batch of five hundred samples. The project inserts control samples that are "blind" to the laboratories in order to assess sampling and analytical error and to provide control data to level results between the annual sampling campaigns. The primary and secondary reference material control samples are important for the levelling and normalisation procedures used by the project as described by Darnley et al 1995. In G-BASE six percent of soil and sediment and eight percent of water samples submitted for analysis are control samples and with the large number of samples collected (Table 1) this provides a very adequate control data set.

Initially the regional geochemistry data was stored in an ORACLE project database set up in the mid-1980s, but as sampling expanded to include more than drainage sediments the data became difficult to manage and some data, such as that on soils, was not being incorporated. The BGS Geochemistry Database was designed in 1992 
(Coats \& Harris 1995) and has since been populated with a wide range of BGS geochemical data, including the G-BASE results. The many ORACLE data tables of the database are linked by a unique sample id keyfield and include laboratory batch information (date of registration, analyte detection limits etc.), site information, analyte determinations and a wide range of ancillary information (such as data confidentiality, grid accuracy and code versions) that provide essential information to the data users. However, it is unfortunate that the staffing resources envisaged in the database design have never been realised and in most instances only the site information and analytical results are routinely loaded.

The excess soil and sediment archive materials are an important resource for the project and have numerous applications ranging from isotopic studies to post-graduate theses. Collation and storage of geochemical samples is an often neglected part of geochemical surveys yet the samples are a valuable resource that needs to be available for future research. The BGS hosts the UK National Geoscience Data Centre (NGDC) and the G-BASE samples form a small part of the national geological sample archive.

\section{PRESENTATION OF RESULTS}

Regional geochemical data are best presented as thematically coloured maps and since the publication of the data for the Great Glen Atlas (BGS 1987) G-BASE has produced atlases containing coloured gridded images for each element. Earlier atlases presented the data as single element symbol maps where lines proportional to an element's concentration were used to present the results (e.g. Regional Geochemical Atlas for Shetland, IGS 1978). The atlas areas were initially based on the national quarter-inch geological map sheet areas. Each atlas puts the regional geochemistry in the context of the geology and other available geoscience information such as mineral 
occurrences. In addition to being a concise summary of a region's geology and mineralisation each atlas contains comprehensive information regarding the behaviour of each element in the temperate surface environment of Great Britain with an increasing emphasis on the diffuse anthropogenic impacts.

In urban areas soil geochemistry is reported as symbol maps rather than gridded images (see Fordyce et al This volume, Figure x). It is inappropriate to produce gridded images at small scales by extrapolating over an inhomogeneous environment making point source contamination blight unnecessarily large areas. Box and whisker plots are also used extensively to compare different sub-sets of data (see Fordyce et al This volume, Figure y).

With the widespread use of PC GIS, map sheet boundaries are now obsolete and digital data are provided to meet the data users requirements. Subsets of G-BASE soil data are increasingly requested for local government administrative boundary areas and stream sediment and water data is more logically interpreted by river catchment areas.

In addition to presenting results in a series of geochemical atlases, G-BASE samples and data are utilised in a wide range of applications and reported in peerreviewed publications. Recent publications have shown how regional geochemical data can be used: to interpret subtle geological changes (Stone et al 2003); to demonstrate the relationships between soils, heavy metal pollution and parent material (Breward 2003, Rawlins et al 2002a and Rawlins et al 2003); in archaeology (Chenery 2001); and surface water research (Hutchins et al 1999). The project has also made significant contributions to documents prepared by BGS for government bodies in response to legislation and directives in connection with pollution and contamination (e.g. Ander 2004 and Smith et al 2002). 


\section{DISCUSSION}

\section{Adapting to the increasing applications of regional geochemical mapping}

The G-BASE geochemical mapping project is a long established and systematic survey the results of which have shown, and continue to show, that the methodology successfully defines the geochemical baseline to a high degree of resolution and produces data with a wide range of applications. The project has demonstrated its ability to adapt to the changing needs of the user community by switching from principally mineral exploration to environmental applications. Nevertheless demand for regional geochemical data to help locate mineralisation continues, albeit periodically, and results will continue to have applicability in this field in ways that we cannot envisage at present. For example, G-BASE drainage sediment data is of great value in connection with current gold exploration in the Sperrin Mountains of Northern Ireland area and has recently also been used in prospectivity mapping in NW Scotland (Colman et al 2003). Since the end of the BGS Mineral Reconnaissance Programme responsibility for following up regional geochemical data now rest with exploration companies who continue to licence and exploit the data in commercial confidence.

The sampling methodology has changed little and remains a cost effective method of geochemical mapping. It is a methodology that has been applied to many countries around the world often with minor modifications to suit the local climatic zone. 
Regional geochemical mapping in the Anti-Atlas region of Morocco (Johnson et al 2001) for example, following an essential orientation exercise determined that the $-250 \mu \mathrm{m}$ fraction of the stream sediment from the semi-arid environment was the most suitable fraction for giving the best contrast between background and anomalies (BGS 1999). This is coarser than the sediment fraction used in the temperate climate of Great Britain but shows the adaptability of the sampling methodology.

The use of graduate students to do the sampling is an important part of the sampling strategy. Since the project started it is estimated that nearly 1000 students have benefited from the experience of collecting geochemical samples with G-BASE during the summer field campaign. Universities do not have the resources to provide such practical training and students find the work a valuable addition to their CVs. Many of the G-BASE samplers have gone on to pursue careers in geochemistry or environmental science.

The demand for geochemical baseline data is increasingly being driven by legislation. Table 4 summarises this legislation that is increasingly being directed by the European Commission. Those empowered to apply or enforce the legislation are generally administrators not geochemists and they will want value added data that shows risks and probabilities of element distributions in the context of guideline values. We must be continually adapting what we produce to meet the users needs.

Although sampling methods have changed little there is still scope for introducing new technologies into the project. Hand held global positioning systems (GPS) were introduced in 2001 following the successful use of GPS during the Morocco geochemical survey. Laptop computers have been used since the mid-1990s for entering field card information into a field database whilst on location. Current initiatives are looking at inputting site information directly into palm-sized computers 
and bar-coding sample bags to make sample checking and collation easier and errorfree. However, the geochemical sampling method is characterised by its relative simplicity and low capital expense. This is particularly important when transferring appropriate technology to developing countries. Any improvements to the sampling methodology, particularly those that rely on increasing complex and expensive equipment, will only be incorporated providing they have a sound cost benefit analysis and a proven reliability.

\section{Longevity of survey and sampling density}

BGS has not completed the geochemical mapping of Great Britain in more than thirtyfive years of sampling and the impact of changing hardware and software used for the chemical and data analyses makes it difficult to maintain a consistency of products. Strict quality control procedures have maintained a consistency in the data but the requirements of the user community have changed with time and a governmentfunded project is very subject to prevailing political whims. G-BASE methodology has been applied by BGS to other long-term surveys (e.g. Sumatra, Indonesia, 1975 to 1994, Machali et al 1997) as well as more rapid regional mapping surveys sampling at rates 5 to 10 times the current G-BASE rate (e.g. Morocco, Johnson et al 2001). Although G-BASE is tied to the summer vacation months by its use of student samplers, it would be desirable to send out more sampling teams during this period so as to get the survey completed as quickly as possible. This makes more efficient use of current software and hardware without the need for constant retraining - it is simply more cost efficient to complete the survey as rapidly as possible.

The speed of geochemical mapping is always a contentious issue between government-funded surveys and the customers who use the data. For example, exploration companies conducting regional surveys will often produce results in a 
matter of weeks and find it hard to comprehend the slowness of national surveys. Projects such as G-BASE operate on a long term strategy that meet the needs of a wide variety of applications by producing a systematic and highly controlled database of geochemical results that will be an asset to the nation and in use for many generations.

The relatively high density of sampling for this multi-media regional survey is responsible for the longevity of the project in two respects. Firstly, there is the obvious need to collect and analyse a larger number of samples requiring more time and budget. The prolonged period of sampling helps to maintain skills and experience amongst BGS staff and enables investments in infra-structure, such as laboratories, that will have a long-term benefit to the organisation. Secondly, use of G-BASE data, particularly in the more recent environmental applications such as identification of heavy metals in garden allotment areas (e.g. Hough et al 2004 and Breward 2003), demonstrates how the survey's data can lead almost directly to site specific follow-up. The high density of sampling has enabled G-BASE to more readily adapt to the changing needs for baseline geochemical data thus ensuring continued support for the project. A higher density of sampling captures more of the variation in the geochemical baseline and better enables us to attribute the reasons for it. As a relatively small island Britain has a very diverse geological history and from an environmental perspective a high population density, two factors that lead to significant variation of the geochemical baseline over small areas.

The sampling density chosen for a regional geochemical survey is always ultimately decided by the time and budget that is available to do it. G-BASE has applied its sampling methodologies, both low and high density, to many regional surveys around the world. The relatively lower density stream sediment surveys such 
as that in Bolivia (1 per $16 \mathrm{~km}^{2}$, Appleton \& Llanos 1985) and Sumatra, Indonesia (1 per $15 \mathrm{~km}^{2}$, Machali et al 1997) have demonstrated the usefulness of low density geochemical mapping, particularly in mineral exploration and elucidating problems of regional geology. G-BASE data itself has been used to simulate variable sampling density (Fordyce et al 1993) in order to demonstrate how low sample density can be utilised for global geochemical mapping.

\section{Method of chemical analysis and elements determined}

The range of analytes determined, the sampling media used and the density of sampling for a regional geochemical survey is always a compromise between the available resources and the demands of the data users. In the early days of the survey exploration companies were demanding a greater range of elements specific to locating mineralisation such as Au and Pt. Now the environmental users of the data want baseline data on contaminants such as $\mathrm{Hg}$ and hazardous organic compounds that are not routinely done by the project because of cost. It is estimated that each site costs $£ 30^{1}$ to sample, for a drainage site that would be $£ 10$ for each of the sediment, water and panned concentrate, and at a soil site $£ 15$ each for the surface and deeper soils. Sample preparation and analysis adds a further $£ 50$ to $£ 60$ to the cost per sample. Additional analyses can only be afforded with extra budget, and this is best achieved by asking the organisations and agencies requiring the additional analyses to contribute to the costs. Excess sample material can be made available, usually as a subset at a reduced sample density or targeted at specific areas. However, many of the additional determinands required mean modification to the sampling procedures with more time being spent at each site and that will also raise the cost of sampling. It has been suggested that the soil samples could be collected adjacent to the drainage site

\footnotetext{
${ }^{1}$ US\$ 55 or Euro 45 at exchange rates, August 2004
} 
effectively reducing the number of sites to be visited by as much as $50 \%$. Although this would be an effective way of reducing costs it is not considered appropriate to combine the soil and drainage surveys into the same sampling grid. Collecting soil samples adjacent to drainage sites will lead to a soil survey that is almost exclusively based on soils derived from alluvial material.

The issue of analytical method whether total or partial is a subject of much discussion when the G-BASE project is involved in the design of geochemical surveys around the world. A true geochemical baseline is one that shows the total concentration of a determinand in the environment and for this reason our preference is to use analytical methods that give total analyses for a wide range of elements. G-BASE's main analytical technique for solids is XRFS, and with the advent of ED XRFS, a large range of elements with good detection limits can be determined on a single sample. Although analytical methods such as ICP-MS following a strong acid extraction are cheaper than XRFS these do not give a truly and consistently total determination for all elements, especially those in minerals resistant to acid attack. Legislative guidelines for element concentrations cannot be based on partial extraction methods otherwise they will need to be cited for a great variety of different mineral assemblages.

Whilst it is important to define regional geochemical baselines on the basis of total analyses, partial and sequential extraction techniques are very valuable in more detailed studies and follow-up work, both in exploration and environmental applications. The bioaccessible fraction of essential and toxic trace elements, for example, is of great importance in geochemistry and health and it is recommended that this fraction can be determined for selective areas using the sample archive. There are several areas of Britain where the arsenic baseline in soils considerably 
exceeds the soil guideline value of $20 \mathrm{mg} / \mathrm{kg}$ (Rawlins et al 2002b). However, a site specific assessment of the risks of high arsenic need to be based not on the total arsenic concentration but on the amount of the bioaccessible arsenic which can be determined using an extraction that mimics the conditions in the human gastrointestinal tract (Ruby et al 1996).

\section{Data conditioning and geochemistry databases}

The G-BASE data conditioning or rendering of the data fit for use has already been introduced earlier in the discussion on data management methodology. The collection of samples over several decades represents a huge input of effort and resources. Managing to keep the resulting data compatible across an equally long period of evolving analytical methodology has also required substantial effort in data management. A strict and well-documented regime of error checking, quality control, quality assurance and standardisation is required.

However, even with good protocols in place, compatibility problems with data will still arise, particularly those resulting from changing analytical methodology. For those elements where analytical precision is poor and concentrations are generally at or below the analytical detection limit (e.g. for G-BASE stream sediments and soils these would be Ag, Cd, Mo, Sb and U) the production of seamless geochemical maps is difficult. Our experience has shown that the detection limit values (dlv) cited by analysts tend to be on the conservative side and results reported below the dlv can define meaningful and real rather than random trends. The values are worth retaining in the geochemistry database and such results should be flagged with a qualifier field as having a below detection issue. For a few elements reporting limit values were once not as low as those reported now and as a result different subsets of data have a varying degree of resolution at low concentrations. As a consequence combining data 
sets from different generations of analytical instrumentation will give rise to maps where the most significant boundaries recognised are due to analytical artefacts. In such instances the only way to combine different data sets to give a seamless geochemical image is to substantially reduce the data's resolution at lower concentrations.

The geochemistry database underpins many of the applications to which the geochemical results are applied. A robustly designed geochemical survey data model is essential and mapping programmes must give sufficient resources not only to the design of the database but also to its maintenance and management. The Geological Survey of Canada, like the BGS, has amassed a large quantity of geochemical data and has a comprehensive relational database model that is universally applicable (Adcock et al 2003).

\section{Future developments}

1) The demand for geochemical data is increasingly being driven by environmental legislation. In Europe the European Commission has launched a number of directives (see Table 4) that have required national governments to apply legislation to clean up and protect the environment from elements and substances that are harmful to the health of the biosphere. Strategies are being developed to apply such legislation and a good national coverage of baseline geochemical data is required. G-BASE needs to accelerate its sampling rate to finish the remaining twenty percent of Great Britain to satisfy the demand for real rather than hypothecated data. The as yet unsampled part of southern Britain is where a third of the country's population lives and is subject to the greatest pressures associated with sustainable development; 
2) the collection of geochemical samples is a cost effective way of mapping and it is the one activity of regional geochemical mapping that has changed little in forty years. Whilst new technologies such as palm-held computers for site information can make the process more efficient, changes need to have a demonstrable cost benefit and proven reliability;

3) additional elements and determinands that are more relevant to environment and health issues need to be added to the geochemical baseline (e.g. Hg, Se, I and toxic organic compounds). Developments in analytical methodology (e.g. use of ED-XRFS for soils and sediments) now make the routine analysis of elements such as Se and I more feasible. Some of these elements and compounds would require changes to the sampling methodology, particularly the sampling for organic compounds, and would change the nature of what up till now had been an inorganic geochemical survey. Such changes will require a substantial increase in resources that can best be achieved with greater cooperation with agencies and organisations specifically interested in the additional determinands;

4) regional geochemical surveys are systematic and do not target specific areas or sites. However, the areas by which the data is "packaged" can be made more appropriate for the main users of the results. From 2005 onwards G-BASE will adopt a drainage catchment approach to sampling rather than an atlas map sheet approach. It is more logical that a geochemical survey based on drainage samples produces results for drainage catchment areas that correspond with those of regulatory agencies such as the UK environmental agencies. In urban areas it is essential to be aware of local issues to which the geochemical mapping can be applied such as contaminated garden allotments. With the 
cooperation and support of the local authorities the soil survey can be supplemented with more targeted sites that will greatly add value to the geochemical survey;

5) the geochemistry database should no longer be seen as a "flat" table of columns representing elements and grid references and rows representing samples. It should be a relational database with many data tables linked by a unique sample identifier. The data tables should contain additional information that allows the users to understand the data limitations and whether or not the results are fit for the purpose for which they are being applied. Such additional information is needed to describe the precision, accuracy and limits of detection of determinands. The BGS Geochemistry Database has been designed to hold this additional information and much of this still needs to be populated for the samples collected. Once the database has sufficient additional information a "data warehouse" can be set up, accessible to the users of the baseline data and in the most suitable format for that user; and

6) developing information technologies, particularly web-based applications, are needed to deliver the data to users. As the data are increasingly being used by non-geochemists it needs to be packaged as "value-added data" in manner usable by administrators who might only want to know whether an element is high, moderate or low in relation to guideline values stipulated in legislation and directives.

This paper is published with the permission of the Director of the British Geological Survey (NERC). The authors acknowledge the effort of several generations of geochemists and students who have worked for BGS on the G-BASE project who 
have ensured that we have inherited well-founded regional geochemical mapping survey.

\section{REFERENCES}

Adcock, S.W., Grunsky, E., LAFrAmboise, R. \& SpIRITO, W.A., 2003. A universal geochemical survey data model. International Association for Mathematical Geological (IAMG) meeting, Portsmouth, UK, September 2003. Paper available at http://geochem.cgkn.net/pp/pdf/Grunsky.pdf

ANDER, E.L., 2004. Baseline concentrations of metals in stream waters and sediments. Commissioned Report Series CR/04/035, British Geological Survey, Keyworth, Nottingham, UK.

Appleton, J.D. \& Llanos, A. 1985. Geochemical Atlas of Eastern Bolivia. British Geological Survey, Keyworth, Nottingham, UK.

BGS, 1987. Regional Geochemical Atlas: Great Glen. British Geological Survey, Keyworth, Nottingham.

BGS, 1996. Regional geochemistry of north-east England. Regional geochemistry. British Geological Survey, Keyworth, Nottingham.

BGS, 1999. Résultats de l'étude d'orientation et analyses chimiques des "Stream Sediments" dans le domaine de l'Anti-Atlas (Maroc). Unpublished Commissioned Report, British Geological Survey, Keyworth, Nottingham.

BREWARD, N., 2003. Heavy-metal contaminated soils associated with drained fenland in Lancashire revealed by BGS Geochemical Survey. Applied Geochemistry, 18, $1663-1670$.

CHENERY, S.R.N., 2001. An evaluation of geochemical fingerprinting for establishing the province of Scottish Red Ware Pottery. Medieval Ceramics, 25, 45-53. 
COATS, J.S. \& HARRIS, J.R., 1995. Database design in geochemistry: BGS experience. In: J.R.A. GILES (Editor), Geological Data Management. Geological Society of London Special Publication, pp. 25-32.

Colman, T.B., Rollin, K.E., McEvoy, F.M., Smith, R.A., BenhaM, A.J., GunN A.G. \& SHAW, M.H. 2003. Minerals information GIS for regional development and inward investment in the northern Highlands of Scotland. British Geological Survey Report CR/03/034N. DTI Minerals Programme Publication No. 12. British geological Survey, Keyworth, Nottingham.

Darnley, A.G., Buorklund, A., Bolviken, B., Gustavsson, N., Koval, P.V., Plant, J.A., Steenfelt, A., Tauchid, M., Xuejing, Xie, 1995. A global geochemical database for environmental and resource management. 19, UNESCO publishing, Paris.

FordyCE, F.M., Brown, S.E., ANDER E.L., RAWLins B.G., O’DONNELl K.E., Lister, T.R., BrEWARD N. \& JOHNSON C.C. (This Volume). GSUE: Urban geochemical mapping in Great Britain.

FordyCe, F.M., GREen, P.M. \& SiMPSON, P.R. 1993. Simulation of regional geochemical survey maps at variable sample density. Journal of Geochemical Exploration, 49, 161-175.

HAWKES, H.E. \& BLOOM, H., 1955. Heavy metals in stream sediment used as exploration guides. Mining Engineer, 8, 1121-1126.

Hough, RL., Breward, N., Young, S.D., Crout, N.M.J. \& Tye, A.M. 2004. Assessing potential risk of heavy metal exposure from consumption of homeproduced vegetables by urban populations. Environmental Health Perspectives, 112(2), 215-221. 
Hutchins, M.G., Smith, B., RAwlins, B.G., \& Lister, T.R., 1999. Temporal and spatial variability of stream waters in Wales, the Welsh borders and part of the West Midlands, UK. 1. Major ion concentrations. Water Research, 33(16), 34793491.

IGS, 1978. Regional Geochemical Atlas: Shetland. Institute of Geological Sciences, London.

InGHAM, M.N. \& VReBOS, B.A.R., 1994. High productivity geochemical XRF analysis. Advances in X-ray Analysis, 37, 717-724.

Johnson, C.C., Brown, S.E. \& Lister, T.R., 2003. G-BASE Field Procedures Manual version 1.1. Internal Report No. IR/03/096N, British Geological Survey, Keyworth, UK.

Johnson, C.C., Flight, D.M.A., Lister, T.R. \& STRUTT, M.H., 2001. La rapport final pour les travaux de recherches géologique pour la realisation de cinq cartes géochimique au 1/100 000 dans le domaine de l'Anti-Atlas (Maroc).

Commissioned Report Series, No.CR/01/031, British Geological Survey, Keyworth, Nottingham.

Jordan, C., Higgins, A.J., HamiLl, K.P. \& Cruickshank, J.G. 2000. The Soil Geochemical Atlas of Northern Ireland : Millennium Edition. Department of Agriculture and Rural Development (DARD), Belfast.

McGrath, S.P. \& LOVELAND, O.J. 1992. The Soil Geochemical Atlas of England and Wales. Blackie Academic \& Professional, London.

Machali, M.A., Johnson, C.C., Crow, M.J., DJumsari, A. \& Sumartono, 1997. Geochemical Atlas of Southern Sumatra. Regioanl Geochemical Atlas Series of Indonesia No. 2. Directorate of Mineral Resources/British Geological Survey, Keyworth, Nottingham, UK/Bandung, Indonesia. 
PlANT, J.A., 1971. Orientation studies on stream sediment sampling for a regional geochemical survey in northern Scotland. Transactions of the Institute Mining \& Metallurgy, 80(section B), 323-346.

Plant, J.A. \& RhIND, D., 1974. Mapping minerals. Geography Magazine, November $1974,123-126$.

Plant, J.A., JefFrey, K., GILl, E. \& FAGE, C., 1975. The systematic determination of accuracy and precision in geochemical exploration data. Journal of Geochemical Exploration, 4, 467-486.

Plant, J.A., Klaver, G., Locutura, J., Salminen, R., Vrana, K. \& Fordyce, F.M., 1997. The Forum of European Geological Surveys Geochemistry Task Group: geochemical inventory. Journal of Geochemical Exploration, 59, 123-146.

RAWLINS, B.G. \& CAVE, M. In press. Investigating multi-element soil geochemical signatures and their potential for use in forensic studies. In: PYE, K. \& CROFT, D. (Eds.) Forensic Geoscience - Principles, Techniques and Applications. Geological Society Special Publication No. 232, Geological Society of London.

RAWlins, B.G., CAVE, M. \& Lister, T.R., 2002a. Arsenic in UK soils: reassessing the risk. Civil Engineering, 150, 187-190.

RAwlins, B.G., Lister, T.R. \& MACKenZIE, A.C., 2002b. Trace metal pollution of soils in Northern England. Environmental Geology, 42, 612-620.

RAWLins, B.G., WEBSTER, R. \& ListeR, T.R., 2003. The influence of parent material on top-soil geochemistry in eastern England. Earth Surface Processes and Landforms, 28, 1389-1409.

Ruby, M.V., Davies, A., Schoof, R., Eberle, S. \& Sellstone, C.M., 1996. Estimation of lead and arsenic bioavailability using a physiologically based extraction test. Environmental Science and Technology, 30, 422-430. 
SAlminen, R., TARVAinen, T., Demetriades, A. \& others, 1998. FOREGS

Geochemical Mapping Field Manual. Guide 47, Geological Survey of Finland, Espoo, Finland.

ShePherd, T.J., Chenery, S., HobBS, S., Horstwood, M., KlinK, B. \& Lord, R. 2003. Lead isotope anatomy of regional heavy metal pollution in the River wear: from 'catchment sources to estuarine sink'. Conference presentation to $6^{\text {th }}$ International Symposium on Environmental Geochemistry, Edinburgh, September 2003. Published abstract reference O167, p 102, conference book of abstracts.

Simpson, P.R., Edmunds, W.M., Breward, N., CoOK, J.M., Flight, D., Hall, G.E.M. \& LISTER, T.R., 1993. Geochemical mapping of stream water for environmental studies and mineral exploration in the UK. Journal Geochemical Exploration, 49, 63-88.

Smith, B., RAwlins, B.G., Ferguson, A.J. \& others, 2002. Information on land quality in England: Sources of information (including background contaminants). R\&D Technical Report P291, UK Environment Agency.

Stone, P., Breward, N. \& Merriman, R., 2003. Mineralogical controls on metal distribution in stream sediment derived from the Caledonides of the Scottish Southern Uplands and English Lake District. Mineralogical Magazine, 67(2), 893906.

Stone, P., Breward, N., Merriman, R., \& Plant, J.A., 2003. Regional geochemistry of cryptic geology: variations in trace element distribution across the Southern Uplands terrane, Scotland. Transactions of the Institute of Mining and Metallurgy (B - Applied Earth Science), 113, B43-B57. 
WebB, J.S., Thornton, I., Thompson, M., Howarth, R.J. \& LOWEnstein, P.L., 2003. The Wolfson geochemical atlas of England and Wales. Clarendon Press, Oxford. 


\section{List of Tables}

Table 1: A table summarising the atlas sample information

Table 2: A table summarising uses for G-BASE data, methods and samples in 2003

Table 3: Table summarising G-BASE sampling and analyses procedures

Table 4: Summary of some UK legislation and European Commission (EC) Directives driving the demand for G-BASE baseline geochemical data

\section{List of Figures}

Figure 1: Map showing areas of Great Britain and Northern Ireland covered by systematic geochemical mapping (shaded).

Figure 2: Diagram showing a typical G-BASE sample site plan

Figure 3: Example of a G-BASE field card for stream sediment

Figure 4: Copper in stream sediments. Image produced using ESRI ArcView GIS software 


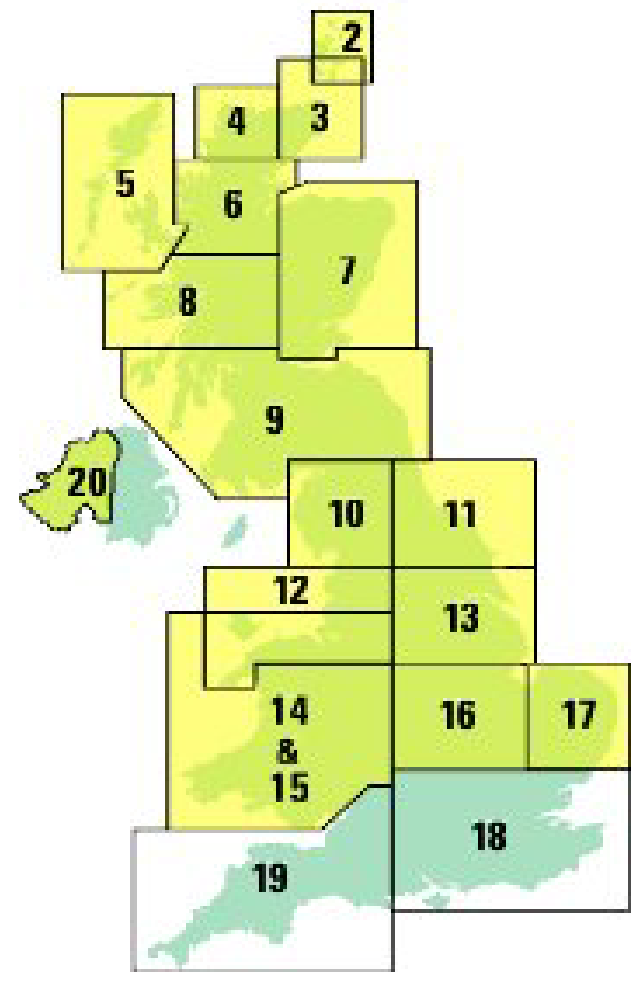

Fig. 1. Map showing areas of Great Britain and Northern Ireland covered by systematic geochemical mapping (shaded). Numbers refer to geochemical atlas areas (see Table 1)

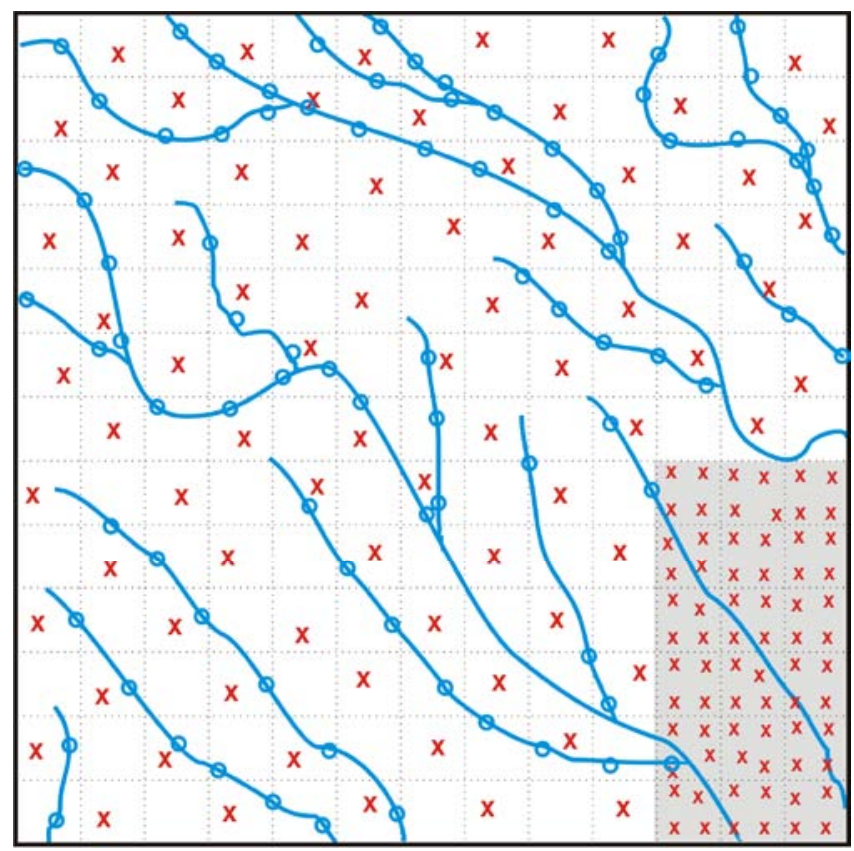

Fig. 2. Diagram showing a typical G-BASE sample site plan

The grid represents one kilometre squares and the urban region is shaded. Circles represent drainage sites (on streams) and crosses represent soil sites 


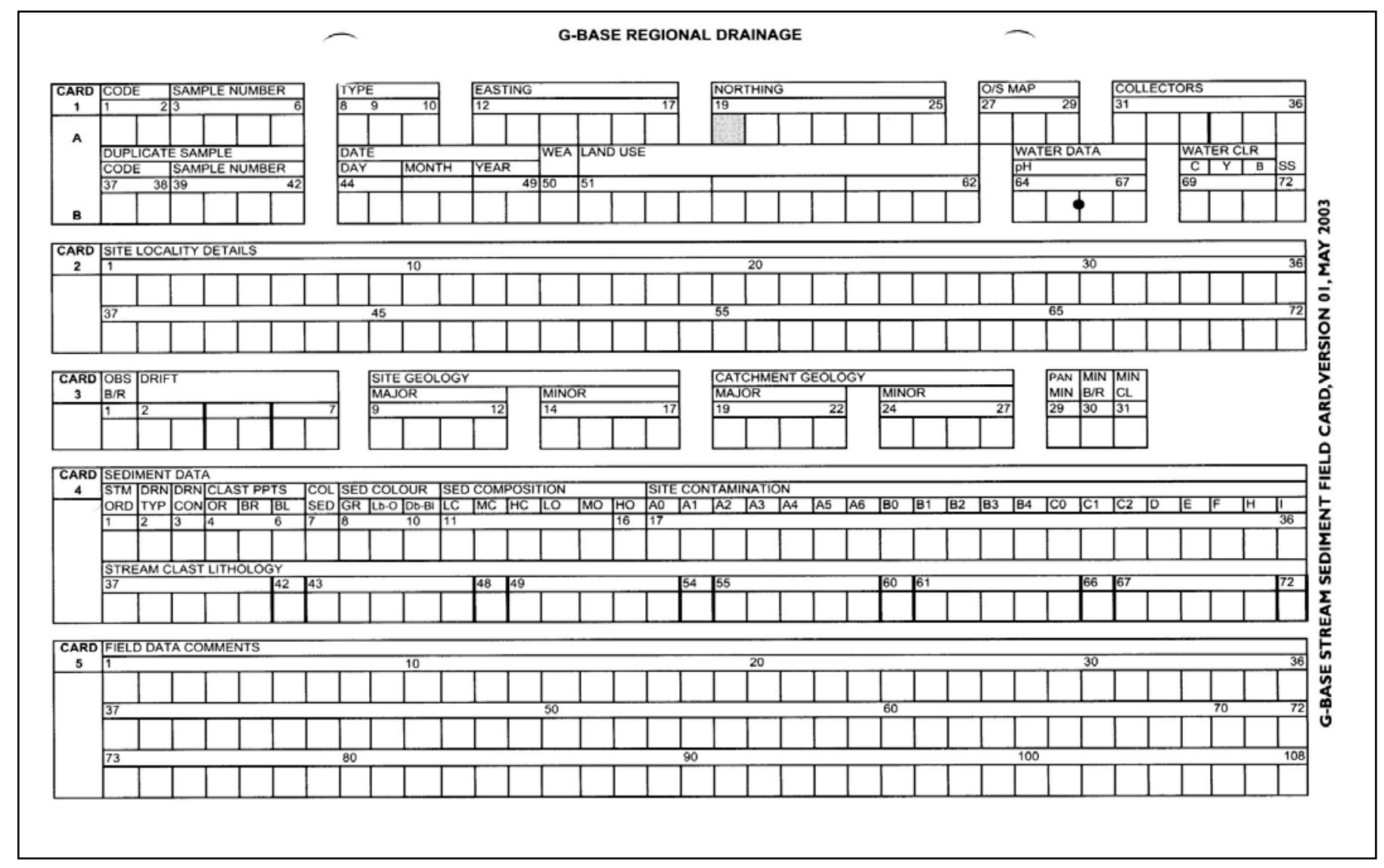

Fig. 3. Example of a G-BASE field card for stream sediment 


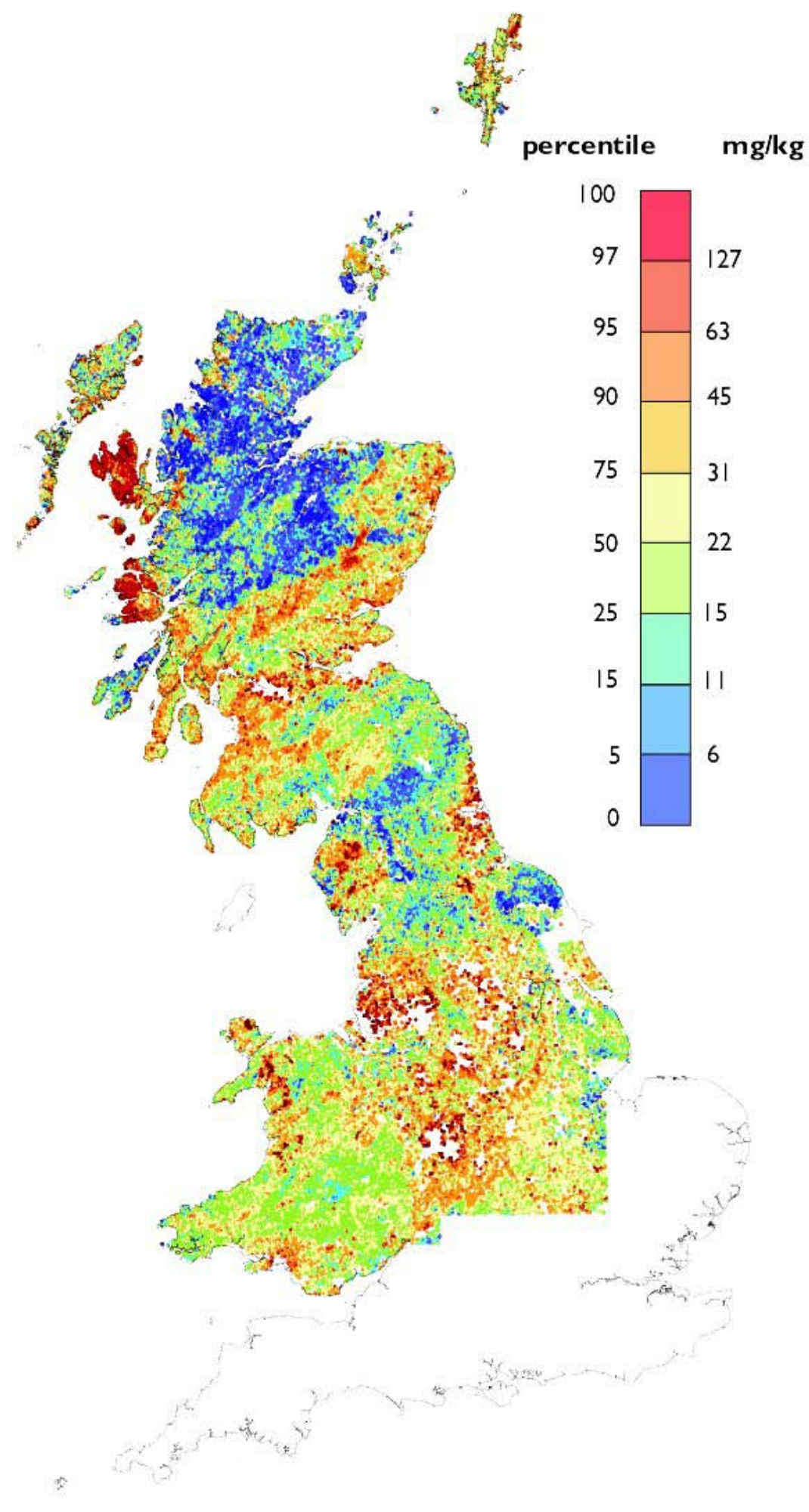

Fig. 4. Copper in stream sediments. Image produced using ESRI ArcView GIS software 
Table 1. A table summarising the atlas sample information

\begin{tabular}{|c|c|c|c|c|c|c|}
\hline & \multirow[t]{2}{*}{ Atlas Name } & \multirow{2}{*}{$\begin{array}{c}\text { Area } \\
\left(\mathrm{km}^{2}\right)\end{array}$} & \multicolumn{3}{|c|}{ Number of samples collected } & \multirow{2}{*}{$\begin{array}{l}\text { Atlas } \\
\text { Published }\end{array}$} \\
\hline & & & $\begin{array}{r}\text { Stream } \\
\text { Sediments } \\
\end{array}$ & $\begin{array}{l}\text { Stream } \\
\text { Waters }\end{array}$ & Soils* & \\
\hline 1 & Shetland & 1410 & 1254 & 1254 & 0 & 1978 \\
\hline 2 & Orkney & 960 & 437 & 672 & 0 & 1978 \\
\hline 3 & $\begin{array}{l}\text { South Orkney and } \\
\text { Caithness }\end{array}$ & 3230 & 1287 & 1287 & 0 & 1978 \\
\hline 4 & Sutherland & 4670 & 2460 & 2622 & 0 & 1982 \\
\hline 5 & Hebrides & 4700 & 3370 & 3370 & 0 & 1983 \\
\hline 6 & Great Glen & 10670 & 7270 & 6933 & 0 & 1987 \\
\hline 7 & East Grampians & 17780 & 9920 & 4230 & 0 & 1991 \\
\hline 8 & Argyll & 12480 & 9560 & 8680 & 0 & 1990 \\
\hline 9 & $\begin{array}{l}\text { Southern Scotland and } \\
\text { N England }\end{array}$ & 27710 & 19000 & 4230 & 0 & 1991 \\
\hline 10 & Lake District & 10030 & 6200 & 2585 & 0 & 1992 \\
\hline 11 & NE England & 9610 & 4306 & 2153 & 502 & 1996 \\
\hline 12 & $\begin{array}{l}\text { NW England \& } \\
\text { N Wales }\end{array}$ & 11180 & 5203 & 3000 & 0 & 1997 \\
\hline 13 & Humber-Trent & 14720 & 4296 & 3101 & 6763 & In Prep \\
\hline 14 & Wales \& W Midlands & 34020 & 18927 & - & 3800 & $\begin{array}{l}2000 \text { (soil \& } \\
\text { stream sed.) }\end{array}$ \\
\hline 15 & Wales \& W Midlands & 34020 & - & 13444 & - & $\begin{array}{l}1999 \text { (stream } \\
\text { water) }\end{array}$ \\
\hline 16 & East Midlands & 17600 & 5047 & 4385 & 7330 & - \\
\hline 17 & East Anglia & 10780 & 1258 & 1082 & 2849 & $\begin{array}{l}\text { sampling in } \\
\text { progress }\end{array}$ \\
\hline 18 & SE England & 27340 & not & sampled & yet & - \\
\hline 19 & SW England & 19380 & not & sampled & yet & - \\
\hline 20 & Northern Ireland (west) & 6550 & 2908 & 2800 & 0 & - \\
\hline
\end{tabular}

* two soil samples are collected at each sampling site. The number in the first column refers to Figure 1 
Table 2. A table summarising uses for G-BASE data, methods and samples in 2003

\begin{tabular}{|c|c|c|}
\hline Application & Detail & Example Reference \\
\hline Regional Geochemical Maps & $\begin{array}{l}\text { Gridded geochemical images } \\
\text { produced as part of regional } \\
\text { geochemical atlas series }\end{array}$ & BGS 1996 \\
\hline Archaeology & $\begin{array}{l}\text { Population provenancing with Sr } \\
\text { isotopes. Mulit-element } \\
\text { fingerprinting for pottery }\end{array}$ & Chenery 2001 \\
\hline Forensic Geochemistry & $\begin{array}{l}\text { Investigating multi-element soil } \\
\text { geochemical signatures and their } \\
\text { potential for use in forensic studies }\end{array}$ & Rawlins \& Cave In Press \\
\hline Geological Mapping & $\begin{array}{l}\text { Mapping drift cover. Crypto- } \\
\text { geological problems }\end{array}$ & $\begin{array}{l}\text { Stone et al } 2003 \\
\text { Stone et al } 2004\end{array}$ \\
\hline $\begin{array}{l}\text { Resource Environment } \\
\text { Survey of Ireland (RESI) }\end{array}$ & $\begin{array}{l}\text { G-BASE has contributed to the } \\
\text { planning and execution of the } \\
\text { Northern Ireland part of this project }\end{array}$ & \\
\hline $\begin{array}{l}\text { University undergraduate and } \\
\text { postgraduate research }\end{array}$ & $\begin{array}{l}\text { Provision of samples, results and } \\
\text { supervision for projects and } \\
\text { MSc/PhD thesis }\end{array}$ & $\begin{array}{l}\text { MSc Thesis, University of } \\
\text { Edinburgh as part of a GIS } \\
\text { on integrated catchment } \\
\text { management }\end{array}$ \\
\hline EU Directive & $\begin{array}{l}\text { Defining levels of baseline } \\
\text { concentrations of metals in stream } \\
\text { sediments and stream water }\end{array}$ & Ander 2004 \\
\hline $\begin{array}{l}\text { Environment protection } \\
\text { strategies }\end{array}$ & $\begin{array}{l}\text { Licencing G-BASE data to local } \\
\text { government authorities for the } \\
\text { purpose of strategy plans in } \\
\text { connection with the Environmental } \\
\text { Protection Act Part IIa }\end{array}$ & \\
\hline General Public enquiries & $\begin{array}{l}\text { Approx. } 60 \text { per year asking about } \\
\text { element behaviour and distribution }\end{array}$ & \\
\hline Mineral exploration & $\begin{array}{l}\text { Geochemical data used as part of } \\
\text { prospectivity modelling. Data } \\
\text { licenced for company in connection } \\
\text { with gold exploration }\end{array}$ & Colman et al 2003 \\
\hline Isotopic provenancing & $\begin{array}{l}\text { Two BGS research projects studying } \\
\text { the distribution of natural and } \\
\text { anthropogenically derived } \mathrm{Pb} \text { and } \mathrm{U}\end{array}$ & Shepherd et al 2003 \\
\hline
\end{tabular}


Table 3. Table summarising G-BASE sampling and analyses procedures

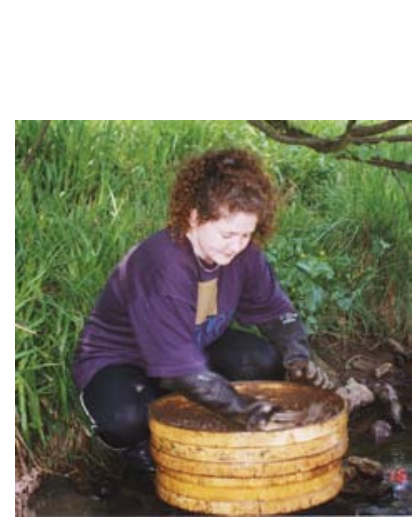

Stream sediment

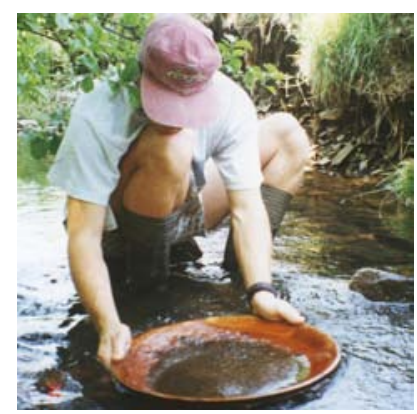

Panned concentrate

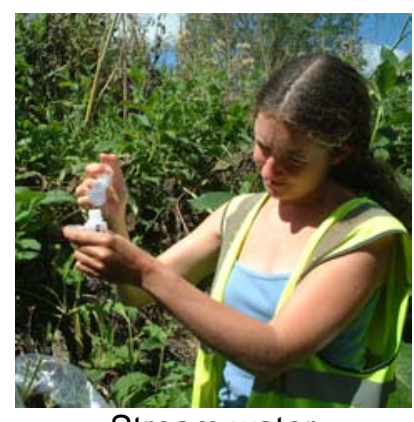

Stream water

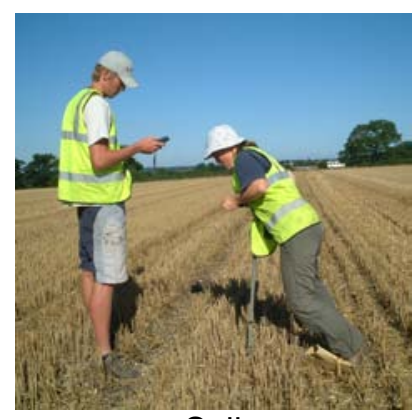

Soil

\section{Sampling}

Sediment is collected from the active drainage channel of $1^{\text {st }}$ or $2^{\text {nd }}$ order streams. The sediment is wet sieved firstly through a $2 \mathrm{~mm}$ nylon screen then a $150 \mu \mathrm{m}$ nylon sieve. The fine stream sediment is collected in a $\mathrm{Kraft}^{\mathrm{TM}}$ paper bag. Sampling density varies according to land use and drainage pattern but averages at one sample every one to two square kilometre.

The $-2 m m+150 \mu m$ fraction from the sieving of the sediment is panned on site in a wooden Malaysian-style "dulang" pan. A full pan is panned down to give a constant volume in the centre of the pan. The heavy minerals are scanned for evidence of mineralisation or pollution.
Sample Preparation and Analyses

Sediments are dried initially by air drying then freeze drying before being pulverised in agate ball mills. Samples are pelletised ready for XRFS analyses at the BGS laboratories in Keyworth, UK. A combination of emission and dispersive techniques gives a range of 48 elements ( $\mathrm{Ag}, \mathrm{Al}, \mathrm{As}$, $\mathrm{Ba}, \mathrm{Bi}, \mathrm{Br}, \mathrm{Ca}, \mathrm{Cd}, \mathrm{Ce}, \mathrm{Co}, \mathrm{Cr}$, $\mathrm{Cs}, \mathrm{Cu}, \mathrm{Fe}, \mathrm{Ga}, \mathrm{Ge}, \mathrm{Hf}, \mathrm{I}, \mathrm{K}, \mathrm{La}$, $\mathrm{Mg}, \mathrm{Mn}, \mathrm{Mo}, \mathrm{Na}, \mathrm{Nb}, \mathrm{Nd}, \mathrm{Ni}, \mathrm{P}$, $\mathrm{Pb}, \mathrm{Rb}, \mathrm{Sb}, \mathrm{Sc}, \mathrm{Se}, \mathrm{Si}, \mathrm{Sm}, \mathrm{Sn}$, Sr, Ta, Te, Th, Ti, TI, U, V, W, Y, $\mathrm{Zn}$ and $\mathrm{Zr}$ )

\section{Panned concentrates are not} routinely analysed or examined in detail. They are stored for future reference and follow-up as required.
Filtered $(0.45 \mu \mathrm{m}$ cellulose filter) and unfiltered waters are collected from the same site as the drainage sediment. Samples are stored in Nalgene ${ }^{\mathrm{TM}}$ bottles and acidified as required by the analytical method.
Soils are collected using a one metre Dutch auger taking five sub-samples at the corners and centre of a $20 \mathrm{~m}$ square. A surface sample (5 to $20 \mathrm{~cm}$ ) and a deeper sample (35 to $50 \mathrm{~cm}$ ) are taken at each site. Samples are collected from alternate $1 \mathrm{~km}$ grid squares though in urban areas sampling density is increased to four samples every $1 \mathrm{~km}^{2}$. Samples are collected in $\mathrm{Kraft}^{\mathrm{TM}}$ paper bags
Alkalinity (by colorimetric titration), $\mathrm{pH}$ and conductivity determined on location. Samples analysed at BGS. ICP-MS: Ag, Al, As, Ba, Be, $\mathrm{Bi}, \mathrm{Cd}, \mathrm{Ce}, \mathrm{Co}, \mathrm{Cr}, \mathrm{Cs}, \mathrm{Cu}, \mathrm{Ho}$, La, Li, Mo, Mn, Nd, Ni, Pb, Rb, $\mathrm{Sb}, \mathrm{Se}, \mathrm{Sn}, \mathrm{Th}, \mathrm{TI}, \mathrm{U}, \mathrm{V}, \mathrm{Y}, \mathrm{Zn}$ \& $\mathrm{Zr}$ [31 elements]. ICP-AES: Al, B, $\mathrm{Ba}, \mathrm{Ca}, \mathrm{Fe}, \mathrm{K}, \mathrm{Mg}, \mathrm{Mn}, \mathrm{Na}, \mathrm{P}, \mathrm{Si}$, $\mathrm{S}$ (reported as $\mathrm{SO}_{4}$ ), Sr \& Zn [14 elements]. Ion Chromatography: $\mathrm{Br}, \mathrm{Cl}, \mathrm{F}, \mathrm{NO}_{2}, \mathrm{NO}_{3}, \mathrm{SO}_{4}, \mathrm{PO}_{4}[7$ ions]. TIC/TOC analyser for Nonpurgeable organic carbon (NPOC) The deeper soil samples are dried then sieved to $-2 \mathrm{~mm}$. Samples are only routinely analysed in areas where drainage is absent. The surface samples are dried and sieved to $-2 \mathrm{~mm}$ and pulverised in agate ball mills then palletised for XRFS analyses as per stream sediment samples. Loss-on-ignition $\left(450^{\circ} \mathrm{C}\right)$ and $\mathrm{pH}$ is also routinely measured for soils. 
Table 4. Summary of some UK legislation and European Commission (EC) Directives driving the demand for G-BASE baseline geochemical data

Legislation/Directive

Environmental Protection Act (1990) Part lla
Summary

This defines contaminated land (Part IIA, Section 78A(2)) and provides a framework for the identification and remediation of such land.

Application of baseline geochemical data

Local authorities have the responsibility to identify and remediate contaminated land commencing with a strategy plan. Baseline geochemical data, particularly soil data for urban areas, can be used as part of the strategy to identify contaminated areas.

\section{EC Water Framework Directive (WFD) (2000/60/EC)}

This requires member states to: meet a good ecological status for water quality objectives (except where deviations from the standard are justified); and to identify basic and supplementary measures to deal with point source and diffuse pollution. The directive will be managed on the basis of River Basin Districts (one or more drainage catchments).
Baseline geochemical data for low order streams can provide information about surface water quality for farmers and those who manage land. Regulatory bodies and administrators can use the data to determine guideline levels for elemental concentrations.

\section{Pollution Prevention Control Act (1999) (PPC)}

This replaces legislation concerned with Integrated Pollution Control (IPC) (derived from the Environmental Protection Act (1990) Part 1) and Local Air Pollution Control (LAPC). It has been created to implement the EC Integrated Pollution Prevention and Control Directive (96/61/EC). Its objective is to control pollution from industry.

\section{EC Sewage Sludge Directive (86/ 278/ EEC)}

This directive seeks to encourage the use of sewage sludge in agriculture but regulates its use in order to protect the environment from its harmful effects.
Baseline geochemical data can be used both by industry and regulators to assess the impact of polluting industries on the environment. The baseline data provides a reference point against which changes can be measured.
Baseline geochemical data can be used to monitor and model the impact on the environment of sewage sludge.
Proposed EC Soil Directive

Directive currently being drafted. The European Union included in the $6^{\text {th }}$ Environmental Action Programme an outline for a future thematic strategy on soil protection leading to a European soil protection policy.
G-BASE has an extensive sample archive and database on the geochemistry of soils collected at a high sampling density. BGS is the only UK organisation systematically sampling soil from urban areas.
Proposed EC Mine Waste Directive
This proposed directive is seen as a supplementary measure to the WFD to minimise the adverse effects on the environment caused by waste from the extractive industries.
Baseline geochemical data can be used to monitor and model the impact on the environment of mine waste.

\section{EC Habitats Directive (92/43/EEC)}

This directive is concerned with the conservation of natural habitats and of wild fauna and flora.
Climatic or anthropogenic changes to the geochemistry of the surface environment that may impact on fauna and flora can be monitored using baseline geochemical data of the surface environment.

\section{EC Landfill Directive (1999/31/EC)}

The Landfill (England and Wales) Regulations of 2002 implement the EC Landfill Directive which aims to prevent or reduce the negative environmental effects of landfill.
Baseline geochemical data can be used to monitor and model the impact on the environment of landfill. 